International

Medical Publisher

http://imedicalpublisher.com

\title{
Review of the Biological Aspects in the Periodontal Ligament and Alveolar Bone Associated with Compression

\section{Abstract}

Background: Tissue remodeling requires protein degradation through a process directly dependent on metalloproteinases - enzymes capable of degrading the majority of proteins in this system. This process is regulated by some enzyme inhibitors, and balance between enzyme and inhibitor activity is fundamental to tissue integrity and health. Bone resorption and formation, and the molecules involved in these processes, raise questions on possible differences in tissue behavior in the system. Histological studies of tissues surrounding teeth that have been subjected to such forces show the presence of tension (associated with bone formation) and compression, which induce bone resorption. The duration of load application is an important parameter in osteoclastogenesis. The present study aimed to analyze the biological aspects associated with in vitro compression of the PL and alveolar bone. To this end, we reviewed articles describing the biological events that occur in the PL and alveolar bone during load application on this system and the possible influence of culture medium on the expression of molecules involved in response to such an event.

Methods: This literature review included articles published between March 2008 and January 2018 describing in vitro laboratory tests and data on load application and its associated biological events in the human PL and alveolar bone, including studies on molecular-expression events and pathways involved in the process.

Conclusions: Intermittent compressive forces stimulate bone resorption in orthodontic treatment, while cyclical forces induce cellular apoptosis at lighter loads than do compressive forces. Both 2D and $3 \mathrm{D}$ cell-culture systems seem to reproduce the physiology of evaluated tissues and are reliable analytical models for research purposes.
Andrea Azevedo', Lydia M. Ferreira², Antonio Aloise ${ }^{3}$

1 Dentist, pos graduation Unifesp. Adma Jafet street, 74, cj 75Bela Vista Brazil.

2 Titular Discipline Plastic Surgery Unifesp.

3 Affiliate of the Discipline of Plastic Surgery at Unifesp.

\section{Contact information:}

Andrea Castilho Soares de Azevedo.

Address: Adma Jafet street, 74, cj 75Bela Vista Brazil. Cod :01308-050

” andreacastilhosa@gmail.com

\author{
Keywords \\ Periodontal Ligament; \\ Osteoclastogenesis; \\ Orthodontic Force; Fibroblasts.
}




\section{Introduction}

Periodontal tissues have the capacity to induce and stimulate remodeling and changes in extracellular matrix as a response to application of force to the periodontal ligament (PL) and alveolar bone. Collagen fibers, the main components of extracellular matrix, are responsible for tissue connection [1]. Tissue remodeling requires protein degradation (to allow subsequent protein resorption) through a process directly dependent on metalloproteinases- enzymes capable of degrading the majority of proteins in this system. This process is regulated by some enzyme inhibitors, and balance between enzyme and inhibitor activity is fundamental to tissue integrity and health [2]. The destabilization that occurs when this balance is upset might give rise to pathological situations, including periodontitis, rheumatoid arthritis, cancer, and malformation [3].

Bone resorption and formation, and the molecules involved in these processes, raise questions on possible differences in tissue behavior in the system. For instance, mechanical forces transferred to teeth during mastication are dissipated through the PL [4]. Histological studies of tissues surrounding teeth that have been subjected to such forces show the presence of tension (associated with bone formation) and compression, which induce bone resorption [5].

Cell-biology research often aims to identify differential expression of molecules during different stages of cell differentiation. Additionally, some studies use in vitro simulation of in vivo tissue physiology, with direct load application on cell [a twodimensional (2D) system]. For instance, fibroblasts in culture can function as dependent units, with the ability to grow and divide normally as they would in vivo, provided the nutrients necessary for growth are available. Fibroblasts require substrate binding for division and growth, and failure in this regard causes proliferation arrest and death [6].

In case of periodontal and peri-implant therapies that, for instance, require an increase in gingivaltissue volume,three-dimensional (3D) culture could help confirm the findings of studies that have used 2D culture techniques [7]. Tissue engineering comprises three essential elements: culture of appropriate cells; a collagen-, bone-, or synthetic-polymer-based matrix; and addition of soluble mediators containing growth factors and adhesins [8]; the matrices must exhibit structural integrity to form new tissues [9]. These techniques are meant to overcome the limitations of plate- or flask-based cell culture in nutrient cell-culture medium in aspects such as transportation to human receptor sites. Carriers would provide a 3D aspect for cell culture and proliferation and would be ideal for fibroblast support and invasion [10].

While high loads might reduce cell viability and induce necrosis or significant tissue damage, periodontal tissue cells might develop osteoblastic activity when subjected to mechanical stress [11]. Loads applied on this system could stimulate osteoclastogenesis-inducing remodeling, which is responsible for cell differentiation, proliferation, and extracellular-matrix expression [12].

Osteoprotegerin (OPG), receptor activator of nuclear factor $\mathrm{kB}$ (RANK), and receptor activator of nuclear factor $k B$ ligand (RANKL) are three molecules involved in bone remodeling. They form a part of the RANKL/OPG/RANK system, which plays a key role in bone resorption and can be modified by osteoblasts, cementoblasts, and osteoclasts [13, 14]. The protein RANKL facilitates bone resorption through osteoclasts and activates bone maturation. Osteoblasts may also produce OPG, which acts as a RANKL receptor and subsequently inhibits bone resorption [15].

The duration of load application is an important parameter in osteoclastogenesis [3; 9]. Periodontalligament cells have the ability to express cytokines (e. g., during an inflammatory event) that inhibit osteoclast-receptor expression [16]. The present study aimed to analyze the biological aspects associated with in vitro compression of the PL and alveolar bone. To this end, we reviewed articles describing 
the biological events that occur in the PL and alveolar bone during load application on this system and the possible influence of culture medium on the expression of molecules involved in response to such an event.

\section{Methods}

This literature review included articles published between March 2008 and January 2018 describing in vitro laboratory tests and data on load application and its associated biological events in the human PL and alveolar bone, including studies on molecular-expression events and pathways involved in the process. In addition, articles on behavior of fibroblasts subjected to cyclic or compressive loads were included.

Articles written in languages other than English and in vivo clinical trials were excluded, as were articles that did not evaluate cells experiencing loads or fibroblasts of the PL. The references of articles that met the inclusion criteria were analyzed to identify studies that could be included in the present review.

\section{Results}

Upon literature search, a total of 53 articles were identified, of which 5 did not meet the inclusion criteria. The remaining 48 articles were analyzed, of which 36 described experiments involving application of compressive forces. Of these 36 articles, 10 involved experiments conducted using 3D systems (i. e., 3D models for cell culture and load application), and the remaining 26 described the application of the same kind of compressive force on a monolayer system, i. e., directly to cells. Only 10 articles described the application of cyclic force to the $\mathrm{PL}$, all of which used monolayer systems, where in loads were applied directly to cells. The reviewed articles can be found on the Table 1 .
Table 1. Research articles included in the present review.

\begin{tabular}{|c|c|c|c|}
\hline Author & Year & Cell culture & Force \\
\hline Henneman [17] & 2008 & $2 \mathrm{D}$ & Compressive \\
\hline Nakajima [18] & 2008 & $2 \mathrm{D}$ & Compressive \\
\hline Rios [19] & 2008 & $2 \mathrm{D}$ & Compressive \\
\hline Bloemen [20] & 2009 & $2 \mathrm{D}$ & Compressive \\
\hline Kook [21] & 2009 & $2 \mathrm{D}$ & Cyclical \\
\hline Nakashima [22] & 2009 & $2 \mathrm{D}$ & Compressive \\
\hline Sanuki [23] & 2010 & $2 \mathrm{D}$ & Compressive \\
\hline Zhu [24] & 2010 & $3 D$ & Compressive \\
\hline Nokhbehsaim [25] & 2010 & $2 \mathrm{D}$ & Cyclical \\
\hline Enokyia [26] & 2010 & $2 \mathrm{D}$ & Compressive \\
\hline Nokhbehsaim [27] & 2011 & $2 \mathrm{D}$ & Compressive \\
\hline Yamamoto [28] & 2011 & $2 \mathrm{D}$ & Compressive \\
\hline Mitsuhashi [29] & 2011 & $2 \mathrm{D}$ & Compressive \\
\hline Diercke [30] & 2011 & $2 \mathrm{D}$ & Compressive \\
\hline Kook [31] & 2011 & $2 \mathrm{D}$ & Compressive \\
\hline Hacopian [3] & 2011 & $2 \mathrm{D}$ & Cyclical \\
\hline Li [32] & 2011 & $3 \mathrm{D}$ & Compressive \\
\hline Nokhbehsaim [33] & 2012 & $2 \mathrm{D}$ & Compressive \\
\hline Drasdo [34] & 2012 & $2 \mathrm{D}$ & Compressive \\
\hline Yu [ 35] & 2012 & $2 \mathrm{D}$ & Cyclical \\
\hline Deschner [36] & 2012 & $3 D$ & Compressive \\
\hline Romer [37] & 2013 & $2 \mathrm{D}$ & Compressive \\
\hline Jacobs [38] & 2013 & $2 \mathrm{D}$ & Compressive \\
\hline Barreto [7] & 2013 & $2 \mathrm{D}$ & Compressive \\
\hline Saminathan [39] & 2013 & $3 \mathrm{D}$ & Compressive \\
\hline Li [40] & 2014 & $2 \mathrm{D}$ & Compressive \\
\hline Shen [41] & 2014 & $2 \mathrm{D}$ & Cyclical \\
\hline Konstantonis [42] & 2014 & $2 \mathrm{D}$ & Cyclical \\
\hline Araujo [43] & 2015 & $2 \mathrm{D}$ & Compressive \\
\hline Jianru [44] & 2015 & $2 \mathrm{D}$ & Compressive \\
\hline Sokos [45] & 2015 & $2 \mathrm{D}$ & Compressive \\
\hline Jacobs [46] & 2015 & $2 \mathrm{D}$ & Compressive \\
\hline Yi [47] & 2015 & $3 D$ & Compressive \\
\hline Aherne [48] & 2015 & $3 \mathrm{D}$ & Compressive \\
\hline
\end{tabular}




\begin{tabular}{|l|l|c|c|}
\hline \multicolumn{1}{|c|}{ Author } & Year & Cell culture & \begin{tabular}{c} 
Force \\
\hline Kawase [49]
\end{tabular} \\
\hline Chen [50] & 2015 & 3D & Compressive \\
\hline Ren [51] & 2016 & 2D & Cyclical \\
\hline Li [52] & 2015 & 2D & Cyclical \\
\hline Wolf [53] & 2015 & 2D & Compressive \\
\hline Otero [54] & 2016 & 3D & Compressive \\
\hline Nettelhoff [55] & 2016 & 2D & Compressive \\
\hline Sheikh [56] & 2017 & 2D & Compressive \\
\hline Feng [57] & 2017 & 3D & Compressive \\
\hline Chen [58] & 2018 & 2D & Compressive \\
\hline Jacobs [59] & 2018 & 2D & Cyclical \\
\hline
\end{tabular}

\section{Discussion}

In order to elucidate the physiology of the human PL and its behavior under mechanical stresses such as orthodontic movement or mastication, several studies have attempted to create in vitro physiological conditions that closely resemble those experienced in vivo. A significant number of studies in this regard have been conducted over the last 10 years; consequently, more than one model type has been proposed for evaluation of PL responses under compressive or cyclic load stimuli. In view of the various compression types and cell-culture models of the PL and surrounding bone, we conducted an analytical literature review of different studies and the implications of their results in relation to compressive models applied to human PL fibroblasts.

Three-dimensional systems allow architectural variations, with porosities that allow structural organization and confer biomolecular functionality [60]. This system could optimize cell distribution and enable in depth evaluation of the bone system, PL, and cementum. The use of multiphasic frameworks helps reestablish structural relationships and improve the accuracy of model tissues by analyzing the most critical points of their structure [61]. Thus, a suitable, rigid, yet porous support would withstand physiological forces and could model tissues of interest. Among currently available options, biodegradable polymers and natural biopolymers are superior for construction of frameworks that mimic the human PL $[62,63]$. Among studies included in the present review, the most common frameworks used for in vitro PL simulation included porous collagen- [64] and hydrogel-based [65] frameworks.

In addition to structural support, 3D systems provide strong cell-medium adhesion, ensuring a more homogeneous dissipation of force around the entire cellular structure than seen in 2D systems. Thus, 3D systems possibly increase cell viability and system integrity [66]. Jianru et al. [44] showed that PL cells grown over a poly-L-glycolic acid-poly-L-lactic acid matrix exhibit significantly decreased OPG/RANKL ratios after 3-6 h under a compressive force, indicating potential induction of osteoclastogenesis. Upon application of a compressive force, OPG expression decreases after 3 $h$, begins to increase after $6 h$, and reaches significantly high levels after $12 \mathrm{~h}$; this regulation of OPG expression indicates suppression of bone resorption. The authors reported that the increase in OPG levels is positively regulated by $\mathrm{KN}-93$, a specific inhibitor of the Ca2+/calmodulin-dependent protein kinase [CAMK] II pathway, and that static compression might activate this pathway. The results of the study by Jianru and coworkers corroborate those of other studies $[10,40,66]$ that also used 3D systems, which indicates that this type of framework regulates the expression of certain molecules, while the different cell-cell contact typologies allowed by these systems induce responses that differ from those of monolayer systems.

Kanzaki et al. [67] and Li et al. [32] demonstrated that the increase in RANKL expression in 
PL cells subjected to compressive forces promotes osteoclast formation and, consequently, dental movement. Bloemen et al. [20] proposed that direct cell-cell contact would create a favorable environment for RANK-RANKL binding, thus preventing osteoclast-inducing OPG-RANKL interaction. Nishijima et al. [68] reported decreased or unaffected OPG expression in PL cells subjected to compression in a 2D monolayer system. This is in contrast to the findings of Jianru et al. [44], who reported that mechanical stimuli cause a regulated and significant increase in OPG expression in 3D culture. The delay in increase in OPG expression could explain post-pressure bone formation, which prevents alveolar bone loss and allows dental movement.

The main advantages of 2D cell-culture systems over 3D systems include environmental control and provisions for cell counting and evaluating cell growth. In addition, most monolayer cultures depend on cell adhesion. Monolayer systems appear to be reliable evaluation systems when compared amongst themselves; however, the frameworks of 3D systems elicit responses that are different from those seen in monolayer systems. Thus, further studies are needed to develop reliable and reproducible laboratory models, dependent on the cell type under evaluation.

Orthodontic movement may consist of torque and dental extrusion and intrusion movements, which are directly related to the magnitude of force applied, position, and adjacent structures [69]. Di Domenico et al. [70] showed that, while relatively light orthodontic forces are not associated with tissue necrosis, heavy forces generate high tension that can promote tissue necrosis, where dental movement would induce bone resorption. An ideal load would allow alveolar bone resorption followed by tissue accommodation and remodeling, thus ensuring the integrity of the system. Casa et al. [71] reported that alveolar-bone resorption in an area undergoing compression would lead to osteoblast and osteoclast activity, resulting in solubilization of minerals and matrix degradation.

Lee et al. [72] investigated the effect of shear forces on human osteoarthritis chondrocyte monolayers. Gene-expression patterns after application of shear stress showed high similarity with those occurring during chondrocyte repair. Moreover, microarray findings suggested a close interaction between shear stress and the pathogenesis of osteoarthritis. The authors explained that these results were attributable to the type of force applied in conjunction with the 2D system used.

Wang et al. [73] investigated whether microRNA 208 is a critical regulator of cardiomyocyte hypertrophy under mechanical stretching. They showed that mechanical elongation significantly increases the expression of both microRNA 208 and the cardiomyocyte hypertrophic protein. On the basis of these results, the authors concluded that cyclic stretching increases the expression of these proteins. In a study using a monolayer system, Li et al. [40] reported that, in a hypoxic environment under conditions of periodontitis or physical stress, the $\mathrm{PL}$ regulates cyclical-stress responses through cellular proliferation and osteogenic differentiation, suggesting that this is a robust model for the study of mechanisms involved in periodontitis.

Jacobs et al. [46] were the first to show that the viability, apoptosis rate, and OPG/RANKL expression levels of fibroblast monolayers under traction loads in the presence of bisphosphonates are dependent on the magnitude of force. Light forces and bisphosphonates increase bone-apposition factors, while heavier forces in combination with bisphosphonates stimulate osteoclastogenesis. Lee et al. [9] showed that the frequency and duration of mechanical signals are important factors that might influence the biological response to application of force. In addition, many studies [9, $36,40]$ have reported that such biological responses are dependent on the type of force applied 
and its variables [including magnitude and duration] and not on the type of culture system.

Studies related to continuous mechanical forces evaluate the response of tension that affects cells to changes in the extracellular environment and assess changes in cell physiology by studying the expression of certain proteins. Cytoskeletal components may have distinct mechanical functions in cells [7]; as a response to force, the cytoskeleton may undergo structural alterations to resist further deformation and reorganization to maintain cellular vitality [74]. The matrix, too, receives a load that induces integrin clustering and activation, thus regulating the intracellular-signaling pathway associated with cell proliferation. These are cellular mechanosensors that might trigger signals leading to modulation of gene expression [4].

It is still unclear to what level cells might distend when subjected to different mechanical stimuli [75]. Wescott et al. [11] evaluated the effect of deformation on cultured fibroblasts and subjected them to different types of stretchingusing a Flexercell strain system. Shear stress can arise during traction and compression, probably because of the fibrous structure of the connective tissue and uneven surface of the alveolar bone [76]. Brown [77] showed that centrifugation can be used to mechanically stimulate and apply fluid shear stress to cell cultures in flasks. The author explained that cell damage is an important issue when studying cellular responses to applied mechanical forces and that cell viability should be measured under all conditions. Appropriate force ranges are selected for a cell viability of $90 \%$, and trypan-10 blue-dye exclusion is the most commonly used test for cell viability.

Howaret al. [78] described an increase in type-। collagen levels in fibroblasts exposed to intermittent biaxial deformity. In contrast, Hacopian et al. [3] showed that the expression of type-I collagen remains unaffected upon application of intermittent mechanical forces. These differences in results are probably attributable to the different types of force used in the two studies. The study considered intermittent force as more suitable for orthodontic movement than continuous force, since periodontal tissue can repair itself after some period. In the study by Howar et al. [78], cyclical and continuous traction forces caused a statistically significant increase in collagenase production in order of magnitude.

Some studies have raised questions about whether cyclical forces induce higher apoptosis rates than do other methods of application of force. Robbling et al. [79] reported that the mechanosensitivity of cells is restored a few hours after loading and that the expression levels of type-I collagenase and matrix metalloproteinase-1 are positively regulated after fibroblast stimulation with continuous centrifugal force, which helps decrease the risk of high rates of apoptosis. In this system, cells are less sensitive to forces applied at the beginning of the next cycle because the stimulation mechanism decreases after inter-activation rest periods.

Chiba et al. [80] showed that changes in microtubule orientation in human PL cells in response to cyclical elongation could represent a mechanism of self-protection. Cyclical force appears to be a reliable and reproducible stimulus model. Several studies have shown that this type of force more closely resembles that exerted by in vivo physiological mechanisms. However, there is a need to evaluate cell vitality, since this mechanism might cause high rates of apoptosis depending on the cell type.

In orthodontic treatment, intermittent compressive force stimulates bone resorption. However, while moderate compressive forces enable active tissue remodeling and dental movement, heavy compressive forces should be avoided in order to prevent tissue damage. Both monolayer and 3D systems seem to reproduce the physiology of the evaluated tissues, but this ability is directly related to the cell type and parameters evaluated in the system. 


\section{Conclusions}

Intermittent compressive forces stimulate bone resorption in orthodontic treatment, while cyclical forces induce cellular apoptosis at lighter loads than do compressive forces. Both 2D and 3D cell-culture systems seem to reproduce the physiology of evaluated tissues and are reliable analytical models for research purposes.

\section{References}

1. Arceo N, Sauk JJ, Moehring J, Foster RA, Somerman MJ. Human Periodontal cells initiate mineral-like nodules in vitro. J Periodontol. 1991; 62:499-503.

2. Lisboa RA, Lisboa FA, Santos GC, Andrade VM, Melo JRC. Matrix metalloproteinase 2 activity decreases in human periodontal ligament fibroblast cultures submitted to simulated orthodontic force. In Vitro Cell Dev Biol-animal 2009; 45: 614-21.

3. Hacopian N, Hosseinzadeh-Nik T, Ghahremani MH, Rahimi HR, Ostad SN. Effects of continuous and interrupted forces on gene transcription in periodontal ligament cells in vitro. Acta Medica Iranica. 2011; 10: 643-9.

4. Anselme K, Ponche A, Bigerelle M. Relative influence of surface topography and surface chemistry on cell response to bone implant materials. Part 2: biological aspects. Proceedings of the Institution of Mechanical Engineers. Journal of Engineering in Medicine. 2010; 224(12): 1487-1507

5. Meikle MC. The tissue, cellular, and molecular regulation of orthodontic tooth movement: 100 years after Carl Sandstedt. Eur J Orthod. 2006; 28: 221-240

6. Moraes AM, Augusto EFP, Castilho LR. Tecnologia do cultivo de células animais de biofármacos a terapia gênica. São Paulo : Rocca, 2007. 503p

7. Barreto $\mathrm{S}$, Clausen $\mathrm{CH}$, Perrault $\mathrm{CH}$ et al. A multi-structural single cell model of force-induced interactions of cytoskeletal components. Biomaterials. 2013 Aug; 34(26): 6119-26

8. Ueda M, Sumi Y, Mizuno H, Honda M, Oda T. Tissue engineering: applications for maxilofacial surgery. Mater. Sci. Eng. 2000; 13: 7-14

9. Lee $Y H$, Nahm DS, Jung YK et al. Differential gene expression of periodontal ligament cells after loading of static compressive force. J Periodontol. 2007:78(3):446-52

10. Zacchi V, Soranzo C, Cortivo R, Radice M, Brun P, Abatangelo G. In vitro engineering of human skin-like tissue. J. Biomed. Mater. Res. 1998; 40:187-94

11. Wescott DC, Pinkerton MN, Gaffey BJ, Beggs KT, Milne TJ, Meikle MC. Osteogenic gene expression by human periodontal ligament cells under cyclic tension. J Dent Res. 2007; 86:1212.

12. Romer $P$. The molecular mechanism behind bone remodelling: $A$ review. Clin Oral Investig. 2009; 13: 355-362
13. Kearns AE, Khosla S, Kostenuik PJ. Receptor activator of nuclear factor kappaB ligand and osteoprotegerin regulation of bone remodeling in health and disease. Endocr Rev. 2008; 29:155-192

14. Lossdorfer $S$, Gotz W and Jager A. Induced changes in RANKL and OPG expression by human PDL cells modify osteoclast biology in a co-culture model with RAW 264. 7 cells. Clin Oral Investig. 2011; 15:941-952

15. Yasuda H, Shima N, Nakagawa N, Yamaguchi K, Kinosaki M, Mochizuki S, Tomoyasu A, Yano K, Goto M, Murakami A, Tsuda E, Morinaga T, Higashio K, Udagawa N, Takahashi N, Suda T. Osteoclast differentiation factor is a ligand for osteoprotegerin/ osteoclastogenesis-inhibitory factor and is identical to TRANCE/ RANKL. Proc Natl Acad Sci U S A. 1998; 95: 3597-3602

16. Scheres N, Laine ML, Sipos PM et al. Periodontal ligament and gingival fibroblastos from periodontitis patients are more active in interaction with Porphyromonas gingivalis. J Periodontal Res. 2011; 46: 407-16

17. Henneman S, Von den Hoff JW, Maltha JC. Mechanobiology of tooth movement. European Journal of Orthodontics. 2008; 30(3): 299-306

18. Nakajima R, Yamaguchi M, Kojima T et al. Effects of compression force on fibroblast growth factor-2 and receptor activator of nuclear factor kappa $B$ ligand production by periodontal ligament cells in vitro. J Periodont Res 2008; 43: 168-173

19. Rios HF1, Ma D, Xie Y, Giannobile WV, Bonewald LF, Conway SJ, Feng JQ. Periostin is essential for the integrity and function of the periodontal ligament during occlusal loading in mice. - J Periodontol. 2008 Aug; 79(8):1480-90

20. Bloemem V, Schoenmaker T, De Vries T, Everts V. Direct cellcell contact between periodontal ligament fibroblasts and osteoclast precursors. J Cell Physiol. 2009; 222:565-73.

21. Kook SH, Son YO, Hwang JM, Kim FM, Lee CB, Jeon YM, Kim JG, Lee JC. Mechanical force inhibits osteoclastogenic potential of human periodontal ligament fibroblasts through OPG production and ERK-mediated signaling.. J Cell Biochem. 2009; 106: $1001-19$

22. Nakashima K1, Tsuruga E, Hisanaga $Y$, Ishikawa $H$, Sawa $Y$. Stretching stimulates fibulin-5 expression and controls microfibril bundles in human periodontal ligament cells. J Periodontal Res. 2009 Oct; 44(5):622-7

23. Sanuki R, Shionome C, Kuwabara A, Mitsui N, Koyama Y, Suzuki $N$, Zhang F, Shimizu N, Maeno M. Compressive force induces osteoclast differentiation via prostaglandin E2 production in MC3T3-E1 cells. Connect Tissue Res. 2010; 51:150-58

24. Zhu QD1, Liu L, Yang YL. Effect of tensile stress on fibronectinintegrins-cytoskeleton in cultured human periodontal ligament fibroblasts. Shanghai Kou Qiang Yi Xue. 2010 Dec; 19(6):601-6.

25. Nokhbehsaim M1, Deschner B, Winter J, Reimann S, Bourauel C, Jepsen S, Jäger A, Deschner J. Contribution of orthodontic load to inflammation-mediated periodontal destruction. J Orofac Orthop. 2010 Nov; 71(6):390-402

26. Enokiya $Y$, Hashimoto S, Muramatsu T, Jung HS, Tazaki M, Inoue T, Abiko $Y$, Shimono $M$. Effect of stretching stress on gene transcription related to early-phase differentiation in rat periodontal ligament cells. Bull Tokyo Dent Coll. 2010; 51(3):129-37 
27. Nokhbehsaim $M$, Deschner B, Bourauel C, Reimann S, Winter J, Rath B, Jäger A, Jepsen S, Deschner J. Interactions of enamel matrix derivative and biomechanical loading in periodontal regenerative healing. J Periodontol. 2011 Dec; 82(12):1725-34

28. Yamamoto $T$, Kita $M$, Yamamoto $K$, Akamatsu $Y$, Oseko $F$, Kanamura N. Mechanical stress enhances production of cytokines in human periodontal ligament cells induced by Porphyromonas gingi- valis. Arch Oral Biol. 2011; 56: 251-57

29. Mitsuhashi M, Yamaguchi $M$, Kojima T, Nakajima R, Kasai $K$. Effects of HSP7O on the compression force-induced TNF and RANKL expression. In human periodontal ligament cells. Inflamm. Res. 2011; 60:187-94

30. Diercke K., Sen S., Kohl A., Lux C. J. and Erber R. Compressiondepend Up-regulation of Ephrin-A2 in PDL Fibroblasts attenuates osteogenesis. J Dent Res. 2011; 90(9): 1108-1115.

31. Kook SH, Jang YS, Lee JC. Human Periodontal Ligament Fibroblasts Stimulate osteoclastogenensis in response to compression force through TNF-x Mediated activation of CD4+T cells. J of Cel Biochemistry. 2011; 112: 2891-2901.

32. Li Y, Zheng W, Liu JS, Wang J, Yang P, Li ML, Zhao ZH Expression of osteoclastogenesis inducers in a tissue model of periodontal ligament under compression. J Dent Res. 2011; 90:115-120

33. Nokhbehsaim M, Deschner B, Winter J, Bourauel C, Jager A, Jepsen S, Deschner J. Anti-inflammatory effects of EMD in the presence of biomechanical loading and interleukin-1b in vitro. Clin Oral Invest. 2012; 16:275-83

34. Drasdo D, Hoehme S. Modelling the impact of granular embedding media, and pulling versus pushing cells on growing cell clones. New Journal of Physics. 2012; 14:1-37

35. Yu Y, Mu J, Fan $Z$ et al. Insulin-like growth factor 1 enhances the proliferation and osteogenic differentiation of human periodontal ligament stem cells via ERK and JNK MAPK pathways. Histochemistry and Cell Biology. 2012; 137(4):513-25

36. Deschner B, Rath B, Jäger A, Deschner J, Denecke B, Memmert S, Götz W. Gene analysis of signal transduction factors and transcription factors in periodontal ligament cells following application of dynamic strain. J Orofac Orthop. 2012 Dec; 73(6):486-95, 497

37. Romer $\mathrm{P}$, Kostler J, Koretsi $\mathrm{V}$, Proff P. Endotoxins potentiate COX-2 and RANKL expression in compressed PDL cells. Clin Oral Invest 2013; 17: 2041-48

38. Jacobs C, Grimm S, Ziebart T, Walter C, Wehrbein H. Osteogenic differentiation of periodontal fibroblasts is dependent on the strength of mechanical strain. Arch Oral Biol. 2013; 58: 896-904

39. Saminathan A., Vinoth K. J., Low H. H., Cao T., Meikle M. C. Engineering three-dimensional constructs of the periodontal ligament in hyaluronan-gelatin hydrogel films and a mechanically active environment. J Periodont Res. 2013; 48: 790-801

40. Li L, Han M-X, Li S et al. Hypoxia regulates the proliferation and osteogenic differentiation of human periodontal ligament cells under cyclic tensile stress via mitogen-activated protein kinase pathways. Journal of Periodontology. 2014; 85(3):498-508
41. Shen T, Qiu L, Chang H, Yang Y, Jian C, Xiong J, Zhou J, Dong S.Cyclic tension promotes osteogenic differentiation in human periodontal ligament stem cells.Int J Clin Exp Pathol. 2014 Oct $15 ; 7(11): 7872-80$

42. Konstantonis D, Papadopoulou A, Makou M, Eliades T, Basdra E, Kletsas D. The role of cellular senescence on the cyclic stretchingmediated activation of MAPK and ALP expression and activity in human periodontal ligament fibroblasts. Exp Gerontol. 2014 Sep; 57:175-80

43. Araujo AS, Fernandes AB, Maciel JV, Netto JN, Bolognese AM. New methodology for evaluating osteoclastic activity induced by orthodontic load. J appl Oral Sci. 2015; 23(1): 19-25

44. Jianru YI, Le LI, Yan YA et al. Static compression regulates OPG expression in periodontal ligament cells via the CAMK II pathway. J Appl Oral Sci. 2015; 23(6): 549-54

45. Sokos D, Everts V, Vries TJ. Role of periodontal ligament fibroblastos in osteoclastogenesis : a review. J Periodont Res. 2015; 50: 152-59

46. Jacobs C, Walter C, Ziebart T, Dirks I, Schramm S, Grimm S, Krieger $\mathrm{E}$, Wehrbein $\mathrm{H}$. Mechanical loading influences the effects of bisphosphonates on human periodontal ligament fibroblastos. Clin Oral Invest. 2015; 19: 699-708

47. Yi L, Dong N, Liu S, Yi Z, Zhang Y. Chemical features of Pericarpium Citri Reticulatae and Pericarpium Citri Reticulatae Viride revealed by GC-MS metabolomics analysis. Food Chem. 2015 Nov 1; 186:192-9.

48. Aherne ST, Madden SF, Hughes DJ, Pardini B, Naccarati A, Levy M, Vodicka P, Neary P, Dowling P, Clynes M. Circulating miRNAs miR-34a and miR-150 associated with colorectal cancer progression. BMC Cancer. 2015 Apr 30; 15:329.

49. Kawase T1, Kamiya M, Kobayashi M, Tanaka T, Okuda K, Wolff LF, Yoshie $H$. The heat-compression technique for the conversion of platelet-rich fibrin preparation to a barrier membrane with a reduced rate of biodegradation. J Biomed Mater Res B Appl Biomater. 2015 May; 103(4): 825-31

50. Chen J, Pu Y, Sun Y, Zhang P, Li Q, Wang K, Wang W, Ma Y, Guan $W$. Biological characterization of metanephric mesenchymal stem cells from the Beijing duck. Exp Ther Med. 2016 Feb; $11(2): 439-447$

51. Ren M, Li K, Wang D, Guo J, Li J, Yang G, Long X, Shen W, Hu R, Wang X, Zeng K. Neurofibromin Regulates Seizure Attacks in the Rat Pilocarpine-Induced Model of Epilepsy. Mol Neurobiol. 2016 Nov; 53(9):6069-6077.

52. Li R, Qi F, Zhang J, Ji Y, Zhang D, Shen Z, Lei W. Antinociceptive effects of dexmedetomidine via spinal substance $P$ and CGRP. Transl Neurosci. 2015 Dec 16; 6(1):259-264.

53. Wolf M, Lossdörfer S, Marciniak J, Römer P, Kirschneck C, Craveiro R, Deschner J, Jäger A. CD8+ T cells mediate the regenerative PTH effect in hPDL cells via Wnt10b signaling. Innate Immun. 2016 Nov; 22(8):674-681.

54. Otero L, Garcia DA, Buitrago LW. Expression and presence of OPG and RANKL mRNA and Protein in human periodontal ligament with orthodontic force. Gene regulation and Systems Biology. 2016; 10:15-20 
55. Nettelhoff L, Grimm S, Jacobs C, Walter C, Goldschmitt P and Wehrbein $\mathrm{H}$. Influence of mechanical compression on human periodontal ligament fibroblasts and osteoblasts. Clin Oral Invest. 2016; 20:621-29

56. Sheikh Z, Qureshi J, Alshahrani AM, Nassar H, Ikeda Y, Glogauer M, Ganss B. Collagen based barrier membranes for periodontal guided bone regeneration applications. Odontology. 2017; 105(1): 1-12

57. Feng L, Zhang $Y$, Kou $X$, Yang R, Liu D, Wang $X$, Song $Y, C_{\text {, ao } H}$, He D, Gan Y, Zhou Y. Cadherin-11 modulates cell morphology and collagen synthesis in periodontal ligament cells under mechanical stress. Angle Orthod. 2017; 87(2); 193-99

58. Chen J, Zhang W, Backman LJ, Kelk P, Danielson P. Mechanical stress potentiates the differentiation of periodontal ligament stem cells into keratocytes. Br J Ophthalmol. 2018; 1-8

59. Jacobs C, Schramm S, Dirks I, Walter C, Pabst A, Meila D, Jacobs C, Wehrbein $\mathrm{H}$. Mechanical loading increases pro-inflammatory effects of nitrogen-containing bisphosphonate in human periodontal fibroblasts. Clin Oral Investig. 2018 Mar; 22(2):901907.

60. Lu HH, Subramony SD, Boushell MK, Zhang X. Tissue Engineering strategies for the regeneration of orthopedic interfaces. Ann Biomed Eng. 2010; 38; 2142-54

61. Dormer NH, Berkland CJ, Detamore MS. Emerging techniques in stratified designs and continuous gradientes for tissue engineering of interfaces. AnnBiomedEng. 2010; 38; 2121-41

62. Frenkel SR, Bradica G, Brekke JH, Goldman SM, leska K, Issack $\mathrm{O}$, et al. Regeneration of articular cartilage-evaluation of osteochondral defect. Repair in the rabbit using multiphasic implants. Osteoarthritis Cartilage. 2005; 13:798-807

63. Wang W, Li B, Yang J, Xin L, Li Y, Yin H, et al. The restoration of full-thickness cartilage defects with BMSCs and TGF-beta 1 loaded PLGA/fibrin gel constructs. Biomaterials. 2010; 31:896473

64. Kon E, Delcogliano M, Filardo G, Fini M, Giarvaresi G, Francioli $S$ et al. Orderly osteochondral regeneration in a sheep model using a novel nano-composite multilayered biomaterial. J Orthop Res. 2010; 28: 116-24

65. Chen J, Chen H, Li P, Diao H, Zhu S, Dong L, et al. Simultaneous regeneration of articular cartilage and subchondral boné in vivo using MSCs induced by a spatially controlled gene system in bilay-ered integrated scaffolds. Biomaterials 2011; 32; 47934805.

66. Jeon JE, Vaquette C, Theodoropoulos C, Klein TJ, Hutmacher DW. Multiphasic Construct studied in an ectopic osteochondral defect. Model. J R Soc Interface 2014; 11: 2014-18

67. Kanzaki H, Chiba M, Shimizu Y, Mitani H. Periodontal ligament cells under stress induce osteoclastogenesis by Receptor Activator of Nuclear Factor kB Ligand up-regulation via prostaglandin E2 synthesis. J Bone Miner Res. 2002; 17: 210-2

68. Nishijima $Y$, Yamaguchi $H$, Kojima T. Levels of RANKL and OPG in gingival crevicular fluid during orthodontic tooth movement and effect of compression force on releases from periodontal ligament cells in vitro. Orthod Craniofac Res. 2006 May; 9(2): $63-70$
69. Nakano K, Okada Y, Saito K, Tanaka Y. Induction of RANKL expression and osteoclast maturation by the binding of fibroblast growth factor 2 to heparan sulfate proteoglycan on rheumatoid synovial fibroblasts. Arthritis Rheum 2004; 50: 2450-2458

70. Di Domenico M, D'Apuzzo F, Feola A et al. Cytokines and VEGF induction in orthodontic movement in animal models. Journal of Biomedicine and Biotechnology 2012; 12: 2012-14

71. Casa MA, Faltin RM, Faltin K, Arana-Chavez VE. Root resorption on torqued human premolars shown by tartrate-resistant acid phosphatase histochemistry and transmission electron microscopy. Angle Orthodontist 2006; 76(6):1015-21

72. Lee MS, Sun M-T, Pang S-T et al. Evaluation of differentially expressed genes by shear stress in human osteoarthritic chondrocytes in vitro. Chang Gung Medical Journal 2009; 32(1):42-50

73. Wang B-W, Wu G-J, Cheng W-P, Shyu K-G. Mechanical stretch via transforming growth factor- $\mathbb{1} 1$ activates microRNA-208a to regulate hypertrophy in cultured rat cardiac myocytes. Journal of the Formosan Medical Association 2013; 112(10):635-43

74. Fletcher DA, Mullins RD. Cell mechanics and the cytoskeleton. Nature. 2010; 463(7280):485-92

75- Myokai F, Oyama M, Nishimura F, Ohira T, Yamamoto T, Arai H, Takashiba S, Murayama Y. Unique genes induced by mechanical stress in periodontal ligament cells. J Periodontal Res 2003; 38(3):255-61

76. Nakao K, Goto T, Gunjigake KK. Intermittent force induces high RANKL expression in human periodontal ligament cells. J Dent Res 2007 Jul; 86(7); 623-8. 477 Brown TD. Techniques for mechanical stimulation of cells in vitro : a review. J Biomech 2000; 33: 3-14

78. Howar PS, Kucich U, Taliwal R, Korostoff JM. Mechanical forces alter extracelular matrix synthesis by human periodontal ligament fibroblastos. J Periodontal Res 1998; 33,8: 500-8

79. Robling $A G$, Burr $D B$, Turner $\mathrm{CH}$. Recovery periods restore mechanosensitivity to dynamically loaded bone. J Exp Biol 2001; 204(19): 3389-99

80. Chiba M, Mitani H. Cytoskeletal changes and system of regulation of alkaline phosphatase activity in human periodontal ligament cells induced by mechanical stress. Cell Biochem Funct 2004; 22(4): 249-56

\section{Publish in International Archives of Medicine}

International Archives of Medicine is an open access journal publishing articles encompassing all aspects of medical science and clinical practice. IAM is considered a megajournal with independent sections on all areas of medicine. IAM is a really international journal with authors and board members from all around the world. 